\title{
The Contribution of Internet Utilization and Learning Creativity on KKPI Subjects in SMK Negeri 2 Bandung
}

\author{
Hendra Widiana, Mukhidin, Widya Puji Astuti \\ Universitas Pendidikan Indonesia \\ Bandung, Indonesia \\ wyanafisha80@gmail.com
}

\begin{abstract}
The purpose of this study is to determine (1) How much contribution of Internet utilization to student learning outcomes on subjects KKPI; (2) How much contribution of learning creativity to student learning outcomes on KKPI subjects; (3) How much contribution of Internet utilization and creativity of learning on student learning outcomes in subjects KKPI at SMK Negeri 2 Bandung. The theoretical foundations raised to support research include the concept of creativity, the use of the Internet in education and educational outcomes. This study was conducted to test the hypothesis: "the contribution of Internet utilization and learning creativity to student learning outcomes on KKPI subject in SMK Negeri 2 Bandung". The research methodology used is correlational method with quantitative approach. Data collection was done through the dispersion of closed questionnaires and test. The 68 respondents in the class XI in the Department of Computer Network Engineering obtained the results of research that the use of the Internet contributes $27.04 \%$ of student learning outcomes, learning creativity contributes $\mathbf{4 2 . 2 5 \%}$ of learning outcomes and the use of the Internet and creativity of learning together -the contribution of $21.16 \%$ to the learning outcomes. Based on these findings, the recommendations that can be given are (1) Internet utilization from the aspect of quality that is need optimization directed as a means of learning to support the learning outcomes. While the utilization of the Internet in terms of quantity that is necessary to increase the capacity of Internet usage time. (2) Student creativity requires further guidance and direction considering the student's growth will always grow so that the aspect of creativity requires continuous optimization. (3) Improvement of learning should be improved through the optimization of aspects affecting student-learning outcomes, whether related to the use of the Internet, creativity and other aspects.
\end{abstract}

Keywords: internet utilization; internet for education; creativity; learning outcomes

\section{INTRODUCTION}

Development of education in Indonesia is basically an effort to renew education into a harmonious system and support the demands of development programs as well as the demands of scientific and technological progress (IPTEK) itself. This is important, considering that education is strategic enough in providing quality human resources for the sustainability of National Development success. Education for the state of Indonesia became a means to immediately align itself with other advanced nations. Education is seen as a vehicle to escape from sustained backwardness, misery and sustainability. The notion of universal education seems to have been adopted internationally, so the aspirations of society for education is no longer limited to the consumtive characteristict, but is a form of investment in human resources are expected to provide benefits in the present and future.

In line with the development of information and communication technology today, the attention and awareness of the importance of the role of information and communication technology for various aspects of government and society highly increase. This is indicated by the establishment of the National ICT Council (DeTIKNas) through Presidential Decree no. 20 of 2006 in charge of providing policy direction and coordinating the application of ICT in Indonesia. So it is with the Ministry of National Education. The application of ICT has been explicitly contained in the 3 pillars of strategic plan policy. First, for equity and expansion of access to education, ICTs serve as a means of implementing distance education. Second, to improve quality, relevance and competitiveness, ICT is used as a medium of learning. Efforts for public governance and imaging, ICTs serve as part of the education management information system.

In order to realize this, various efforts have been made by the Ministry of National Education starting from the establishment of ICT infrastructure to various forms and types of learning content. In addition, to ensure that all goes well, the Ministry of National Education has issued Permendiknas (National Education System) year No.38 of 2008 on the management of ICT in MoNE environment. Thus, facilities and infrastructure to support implementation of ICT in education in Indonesia has been there and ready to be implemented.

The problem now is, how to build a situation that can arouse to the student the type of learning experience desired. The main effort that encourages the formation of learning experiences is the individual creativity of the students themselves in the completion of their learning tasks. As Oteng Sutisna (1985: 48) explains: 
The term learning experience is not the same as the content of the lesson or the activities the teacher undertakes. The term learning experience refers more to the student's interactions with the external conditions in the environment against them where they can react. Learning occurs through the student's active behavior; What he learns is what he does, not what the teacher does.

The above understanding implicitly explains that, to acquire the kind of learning experience that is expected to be pursued by providing opportunities or building situations that allow individual creativity to emerge.

Creativity is considered necessary because it can support the success of life, with creativity is the human can actualize himself, see the various possibilities of problem solving, provide satisfaction to the individual and enable people to improve the quality of life (Munandar, 2004: 31). Education demands creativity in teaching and learning process, Its manifestation depends not only on the school as the education provider but also on the existence of the students. The existence of students not as an object but as a subject of education within which there are different talents, interests, abilities and motivations. According to Supriadi (1994: 20) that "... personality profile of creative individuals in the narrow sense includes attitude, interests, motivation, and style of thinking". All of these show the unique characteristics of students who have an effect on the success of education. Teacher's job is to help students achieve their goals, meaning that teachers should deal more with strategies to provide information and students who must be actively seeking information. Thus, creativity is one of the factors for students to be able to respond back to the learning materials actively, not having to wait for information from the teacher. Therefore, creativity has a share in the success of education, especially in this case related subjects KKPI.

The quality of learning outcomes in subjects KKPI, especially related to internet material in addition influenced by the creativity of student learning will also be influenced by the use of the Internet as a media practice of the theory that has been submitted. The more intensive a student utilizes the internet as a means of practicing hence enabling the improvement of knowledge and skill of student in using internet.

\section{A. Formulation of the problem}

Based on the background of problems that have been described in advance, then the formulation of the problem to be reviewed is:

1. How much contribution of internet utilization to student learning outcomes on subjects KKPI in SMK Negeri 2 Bandung?

2. How much does the contribution of learning creativity to student learning outcomes on subjects KKPI in SMK Negeri 2 Bandung?

3. How much contribution of internet utilization and learning creativity to student learning outcomes on subjects KKPI in SMK Negeri 2 Bandung?

\section{B. Research Purposes}

The research objectives to be achieved in this research are:

1. Knowing the amount of contribution of internet utilization to student learning outcomes in SMK Negeri 2 Bandung.

2. Knowing the contribution of learning creativity to student learning outcomes in SMK Negeri 2 Bandung.

3. Knowing the contribution of Internet utilization and creativity of learning to student learning outcomes in SMK Negeri 2 Bandung.

\section{Benefits of research}

Through this research, it is expected to obtain a value of benefits that include:

1. This study can provide benefits for the assessment of KKPI learning system and student learning creativity so that it can be used as an improvement for the school in providing educational services.

2. As an input material to teachers, both KKPI subject teachers and other teachers about the use of the internet in the learning process.

3. For students, through the utilization of the internet is expected to create an atmosphere of learning that makes students feel that the use of the Internet is fun, fosters a positive attitude, motivation, and confidence. Thus the students can develop the process of thinking so as to enhance the creativity of learning and ultimately impact on improving learning outcomes.

4. Increase the knowledge and experience of the author in the field of research in terms of practical and theoretical about the contribution of Internet utilization and creativity of student learning on learning outcomes.

5. Overall expected the results of this study can make a significant contribution to the development of education in SMK Negeri 2 Bandung.

\section{Research Hypothesis}

Based on the problems that have been discussed previously, then the hypothesis established in this study are as follows:

1. There is a positive and significant contribution of the internet utilization of student learning outcomes on subjects KKPI in SMK Negeri 2 Bandung.

2. There is a positive contribution and significant learning creativity to student learning outcomes on subjects KKPI in SMK Negeri 2 Bandung.

3. There is a positive and significant contribution of Internet utilization and creativity of learning to student learning outcomes on subjects KKPI in SMK Negeri 2 Bandung.

\section{THEORETICAL BASIS}

\section{A. Concept of Learning Creativity}

Creativity is a complex field of study, arising from differences in defining the meaning of creativity. This definition is closely related to the basic theory on which it is based. The different perspective on the definition of creativity is not without cause, Supriadi (2002: 6) states that the 
difference is caused by two things. First, as a "hypothetical construct", it means that creativity is a complex and multidimensional complex of psychology, containing multiple interpretations. Second, the definitions of creativity provide different pressures, depending on the definition maker's definition.

1. Rhodes (1961, Munandar, U. 2004: 20 and Supriyadi, D., 2001: 7) based on a study of 40 definitions of creativity concluded that: "creativity is generally defined as the personal, process, (Product), and pusher (press). That understanding became known as "Four P's of Creativity". Further explained that creativity as:

2. Personal. According Utami Munandar creativity in terms of personal dimensions or person is an expression of the uniqueness of individuals in interaction with the environment. From unique and original personal expressions, new ideas and innovative products are expected to arise.

3. Drivers or Press. Press or impulse is the impulse of the environment and from the self to be creative to produce something. Creativity is the result of interaction between individuals and their environment. The creative potential of a person must be supported by the situation and the environment in order to create something innovative. In addition, there must also be a push from within because the potential that is not forced from within will not achieve creative excellence. Creative potential can develop in a conducive environment, but can also be inhibited by a non-supportive environment. In the family, school, work and community environment there must be an appreciation and support for the creative attitudes and behaviors of individuals and groups of individuals.

4. Process. It takes a process to be self-busy creatively in carrying out an activity to produce something creatively.

5. Products. Creativity in terms of product dimensions is defined as the ability to create new products or form new combinations between existing and previously known elements.

Munandar (2004: 47) further concludes that "these four P's are interrelated: Creative individuals engage in the creative process, and with the support and encouragement (press) of the environment producing creative products". So the definition of creativity based on the description of the experts above can be concluded that creativity as the ability possessed by each person to be able to produce creative action which is the interaction of personal factors, drivers, processes and products. Creative action is an action to generate something new or find new methods of problem solving by combining the existing elements and based on a smooth, smooth, original, and elaborate way of thinking. Conclusion on this understanding the author uses as a basis for determining the concept of student creativity.

Creative teachers are, teachers who are able to create a learning environment conducive to the development of creativity; Teachers who are able to apply learning techniques that stimulate students' creative thinking by integrating cognitive and affective developments; Teachers who have aptitude and non aptitude characteristics of creativity.
Creativity is the result of the interaction process between individuals and their environment (Munandar, 2004: 76). A person influences and is influenced by the environment in which he is located, and thus both the variables within the individual and within the environment can support or hamper creative effort.

Students 'creativity in school is strongly influenced by the learning environment created by teachers in the classroom, how teachers behave and behave towards students will have an effect on students' creativity development. Munandar (2004: 100) shows the extent to which a child's potential is nurtured and developed is also a function of teacher and parent attitudes toward creativity. The more positive the attitude of the teacher towards the creative personal characteristics will be more conducive to the learning environment he created. This research is reinforced by Munandar's opinion (2004: 103) that the optimal development of students' creative thinking ability is closely related to the way teachers teach.

The teachers that need to do in the classroom in order for creativity to flourish is to be open to students' interests and ideas, allowing students time to think and develop creative ideas or ideas, create a warm, supportive atmosphere to provide security for explorative thinking, To students to participate and make decisions, to encourage all children to be involved in problem solving and to support student ideas and problemsolving plans.

Being concerned with the various opinions mentioned above can be concluded that creativity is the ability to convey ideas, take action, change the mindset, solve problems or develop new concepts in unconventional ways. Based on this understanding, the aspects of creativity are: (1) have strong imagination, (2) have many initiatives, (3) have big energy, (4) long-term orientation, (5) have firm attitude, (6) ) Have a broad interest, (7) have the nature of curiosity, (8) dare to take risks, (9) dare to argue, and (10) have confidence.

\section{B. Characteristics of Creativity}

The characteristics of creativity is a criterion of creative people based on the personality traits they possess. According to Guilford in Supriadi (2002: 13) states that:

Creative people have personality traits that are significantly different from those less creative. These personality traits become the criteria for identifying creative people.

Then Guilford in Munandar (1992: 88) distinguishes the characteristics of creativity in two groups, namely aptitude and non aptitude. Aptitude characteristics are characteristics related to cognition and thought processes, such as fluency, flexibility, originality, elaboration, and evaluation are the characteristics of creativity associated with one's thinking ability, while the nonaptitude characteristics are characteristics Related to attitudes or feelings, such as curiosity, interest in composite tasks that are perceived as a challenge, dare to take risks to make mistakes or to be criticized by others, not easily discouraged, appreciate beauty, have a sense of humor, New experiences, can appreciate both yourself and others. 
According to Fuad Nashory and Rachmy Diana Mucharam (2002: 33) states that:

Kreativitas adalah kemampuan untuk menciptakan sesuatu yang baru. Hasil karya atau ide-ide baru itu sebelumnya tidak dikenal oleh pembuatnya maupun orang lain. Kemampuan ini merupakan aktivitas imajinatif yang hasilnya merupakan pembentukan kombinasi dari informasi yang diperoleh dari pengalaman-pengalaman sebelumnya yang menjadi hal yang baru, berarti dan bermanfaat.

Bobbi DePorter and Mike Hernacki (Fuad Nashory and Rachmy Diana Mucharam, 2002: 34) define 'creativity as seeing things that others see but thinking of things that others do not think'. While Guilford (Fuad Nashory and Rachmy Diana Mucharam, 2002: 34) reveals that: 'Creativity is the ability to think diverging to explore various alternative answers to a problem, which is just as true'. About the properties of creativity, David Campbell (Fuad Nashory and Rachmy Diana Mucharam, 2002: 34) suggests that creativity is an activity that produces results that are:

1. New or novel, which is defined as innovative, nothing before, fresh, interesting, strange and surprising.

2. Useful or useful, interpreted as more comfortable, more practical, simplify, encourage, develop, overcome difficulties, bring good results.

3. Understandable or understandable, defined as the work created or created can be understood by others.

Meanwhile, Fieldman as quoted by Conny Semiawan et al (Fuad Nashory and Rachmy Diana Mucharam, 2002: 34) argues that the main nature of creativity is to have a new nature. The new nature has the following characteristics:

1. A completely new product that previously did not exist.

2. Products that have new properties as a result of a combination of some pre-existing products

3. A product that is new as a result of innovation and development (evolution) of things that already exist.

Psychologist Eisner argues that an entirely new product is a product produced by an imaginative process or often called boundary pusher, which is not tied to the boundaries normally held by society. Still according to Eisner, there is another type of product that is new but has characteristics contrary to the truth or assumptions held by society in general, the type of creativity called boundary-breaking.

Agreeing with the views of Campbell and Eisner, creativity experts Harrington et al quoted Fuad Nashory and Rachmy Diana Mucharam (2002: 35) states that the new nature is a feature of the product of creativity. According to him, the level or degree of creativity seen from the level of novelty. This novelty can be calculated statistically in terms of scarcity. The new nature of creativity, according to Morgan, is usually something unexpected. In addition, there is the possibility of new products that are often considered strange or unusual. This is according to Hayes, among others due to the existence of modifications that may conflict with the previous state. The new nature of a strange or unusual and even contradictory creativity product above often takes a long time to be accepted by society. This is one reason why creative people need to have certain qualities, such as assertive, independent, confident, and risk-taking courage.

In addition to novelty (novel), some experts claim that the characteristic nature of creativity comes with useful properties. Products that have beneficial properties are creativity products that are really useful for the community. A concrete product is a work that can be directly used by the community. While the abstract product is an invention in the form of a concept of thought. Furthermore, what is understandable is that the works created and introduced by the creator can be understood or understood by others.

The important factors that characterize Guilford's creative thinking ability (Fuad Nashory and Rachmy Diana Mucharam, 2002: 43) are:

1. Fluency of thinking (fluency of thinking), namely the ability to generate many ideas that come out of a person's thinking appropriately. In the fluency of thinking that is emphasized is quantity, not quality.

2. Flexibility, ie the ability to produce ideas, answers or varied questions, can see a problem from different perspectives, and be able to use a variety of approaches or ways of thinking. A creative person is a flexible person in thinking. They can easily abandon old ways of thinking and replace with new ways of thinking.

3. Elaboration (elaboration), the ability to develop ideas and add or detail details of an object, idea or situation so that it becomes more interesting.

4. Originality, ie the ability to incubate unusual ideas or the ability to trigger original ideas.

From his research, Guilford (Fuad Nashory and Rachmy Diana Mucharam, 2002: 45) concluded that there are four forms of fluency of thinking, namely:

1. Smooth word (word fluency), which is the ability to generate words from a letter or a combination of letters. This ability is not easy to see the meaning and importance in everyday life. This ability is related to the field of science and art.

2. The smoothness of the association (association fluency). The best indication for the smoothness of an association is a test that asks for testies to produce as many equations as possible from the words given in a limited time. The words given must have meaning.

3. Smooth expression (expressional fluency). The test that asks for testies to produce sentences. The typical test that reveals this ability is that words must be compiled quickly and must meet grammatical requirements.

4. Ideal fluency, is the ability to generate ideas that meet certain conditions in a limited time.

Furthermore, according to the newer theories of creativity, the "three facet model of creativity" by Sternberg (1988) cited Munandar (2004: 20), namely 'creativity is a typical meeting 
point between the three psychological attributes: intelligence, cognitive style, and personality /motivation. Together these three facets of mind help to understand what lies behind creative individuals'.

\section{Internet}

Various definitions put forward by experts and technicians involved in the internet world, including Oetomo (2002: 52), states that the internet is a very large computer network consisting of small networks that are connected to the entire world. The same sense is also expressed by Ramadan (2005: 1 ), saying that "the internet is a communication system capable of connecting computer networks around the world". Meanwhile, the definition of the Internet according to Heywood (1999: 8) is a public computer system, which is connected globally and using TCP / IP as a packet switching communication protocol.

The Internet is a global network that connects thousands and even millions of computer networks (local/ wide area network) and personal computers, which allows each computer connected to it can communicate with each other. This network is not an organization or institution, because neither party organizes and owns it.

Technically the Internet as a protocol (rules/ agreements), because to be interconnected and communicate every computer must use the standard protocol that is TCP/IP (Transmission Control Protocol/ Internet Protocol) as a commonly agreed protocol standard. In other words though a technically the Internet as a protocol (rules/agreements), because to be interconnected and communicate each computer must be a standard protocol that is TCP/ IP (Transmission Control Protocol/ Internet Protocol) as a commonly agreed protocol standard. In other words, even if a computer is connected to the Internet network, but if it does not use the agreed communication standards of transmission and acceptance, the computer can not communicate.

Uter is connected to the Internet network, but if it does not use the agreed communication standards of transmission and acceptance, it still can not communicate.

From some of the above definitions, researchers can conclude that the Internet is a collection of various computer machines and computer networks around the world that are connected globally using a set of rules that is TCP/ IP protocol. Computer machines can be a server, PC, mobile phone, PDA, and others. Thus the internet can be viewed as a system of communication and information systems that are connected globally (worldwide) that can be accessed anywhere using a computer device or other communication devices. In simple terms the internet can be described as follows (Fig.1).

\section{RESEARCH METHODOLOGY}

The appropriate method to use in this research is correlation method (correlation study) supported by quantitative approach. Quantitative approach is a research approach that is done by measuring the indicators of the variables so that it can obtain the general picture and simultaneously the conclusions about the problems studied.

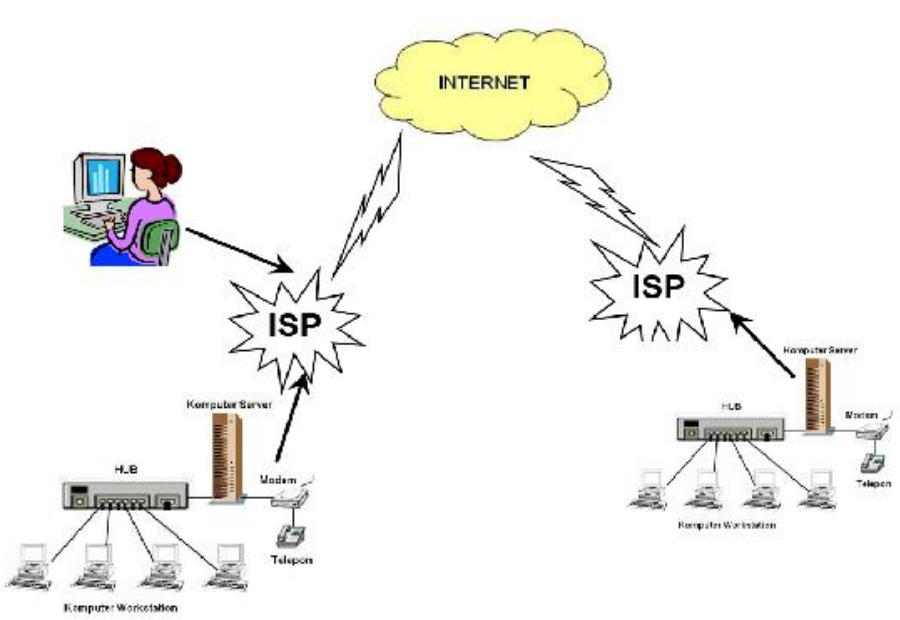

Fig. 1. Internetilustration

\section{RESEARCH RESULTS}

Based on the number of variables and referring to the research problem, the description of data can be grouped into three parts, namely: 1) Internet Utilization (X1); 2) Learning creativity $(\mathrm{X} 2 \neg)$; 3) student learning outcomes (Y).

\section{A. Internet Utilization Variable (X1)}

Respondents in this study amounted to 68 students of SMK Negeri 2 Bandung. The results showed that the mean or average value of internet utilization is 72.78 with the standard deviation is 8.74 . Range is the range between data minimun with maximun and known by 34. Data Minimun equal to 54 with data Maximum 90. While distribution of research data is presented in Table I.

\section{TABLE I. DISTRIBUTION OFSCORE FREQUENCY ON} INTERNETUTILIZATION

\begin{tabular}{|c|c|c|c|c|c|}
\hline INTERVAL & $\mathbf{F}$ & $\mathbf{X}$ & $\mathbf{X}^{\mathbf{2}}$ & $\mathbf{F X}$ & $\mathbf{F X}^{\mathbf{2}}$ \\
\hline \hline $90-86$ & 2 & 88 & 7744 & 176 & 15488 \\
\hline $85-81$ & 14 & 83 & 6889 & 1162 & 96446 \\
\hline $80-76$ & 11 & 78 & 6084 & 858 & 66924 \\
\hline $75-71$ & 17 & 73 & 5329 & 1241 & 90593 \\
\hline $70-66$ & 9 & 68 & 4624 & 612 & 41616 \\
\hline $65-61$ & 9 & 63 & 3969 & 567 & 35721 \\
\hline $60-56$ & 3 & 58 & 3364 & 174 & 10092 \\
\hline $55-51$ & 3 & 53 & 2809 & 159 & 8427 \\
\hline & 68 & 564 & 40812 & 4949 & 365307 \\
\hline
\end{tabular}

The propensity to spread the distribution of Internet Utility variable scores is presented in the Fig.2. 


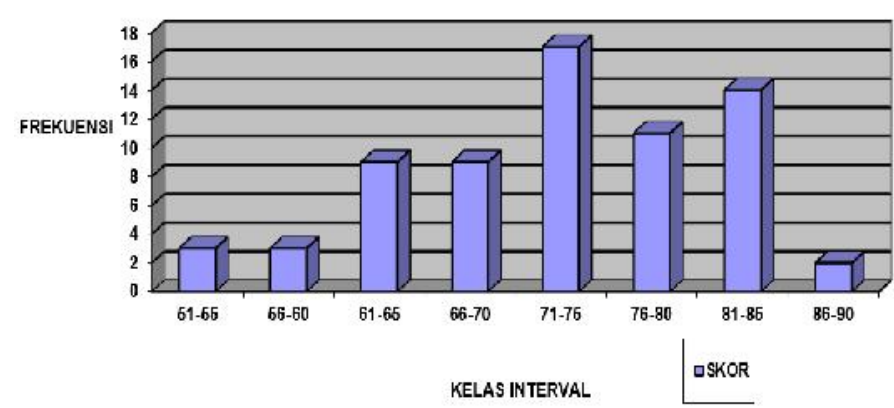

Further description of Utilization of the Internet can be classified the picture through the table results of the tendency of the average of respondents as follows (Table II).

Fig. 2. Histogram Score on Internet Utilization

TABLE II. TABLE 4.2. AVERAGE TREND OF INTERNET USE SCORE IN SMK NEGERI 2 BANDUNG

\begin{tabular}{|c|c|c|c|c|c|c|c|c|c|c|c|c|c|c|}
\hline \multirow{3}{*}{ INDICATORS } & \multirow{3}{*}{ No. Item } & \multicolumn{10}{|c|}{ Key answers } & \multirow{2}{*}{\multicolumn{2}{|c|}{ score. }} & \multirow{3}{*}{ Averange } \\
\hline & & \multicolumn{2}{|c|}{5} & \multicolumn{2}{|c|}{4} & \multicolumn{2}{|c|}{3} & \multicolumn{2}{|c|}{2} & \multicolumn{2}{|c|}{1} & & & \\
\hline & & $\mathbf{F}$ & $\mathbf{X}$ & $\mathbf{F}$ & $\mathbf{X}$ & $\mathbf{F}$ & $\mathbf{X}$ & $\mathbf{F}$ & $\mathbf{X}$ & $\mathbf{F}$ & $\mathbf{X}$ & $\mathbf{F}$ & $\mathbf{X}$ & \\
\hline \multirow{8}{*}{$\begin{array}{l}\text { a) Internet as a } \\
\text { medium of learning }\end{array}$} & 1 & 10 & 50 & 37 & 148 & 21 & 63 & 0 & 0 & 0 & 0 & 68 & 261 & 3.84 \\
\hline & 2 & 13 & 65 & 30 & 120 & 23 & 69 & 2 & 4 & 0 & 0 & 68 & 258 & 3.79 \\
\hline & 3 & 12 & 60 & 34 & 136 & 20 & 60 & 2 & 4 & 0 & 0 & 68 & 260 & 3.82 \\
\hline & 4 & 13 & 65 & 42 & 168 & 13 & 39 & 0 & 0 & 0 & 0 & 68 & 272 & 4.00 \\
\hline & 5 & 5 & 25 & 11 & 44 & 49 & 147 & 2 & 4 & 1 & 1 & 68 & 221 & 3.25 \\
\hline & 6 & 9 & 45 & 22 & 88 & 30 & 90 & 7 & 14 & 0 & 0 & 68 & 237 & 3.49 \\
\hline & 7 & 12 & 60 & 15 & 60 & 32 & 96 & 7 & 14 & 2 & 2 & 68 & 232 & 3.41 \\
\hline & \multicolumn{14}{|c|}{ Average Indicators $=25,60: 7=3,66$} \\
\hline \multirow{9}{*}{$\begin{array}{l}b \text { ) Use of the Internet } \\
\text { as a learning resource / } \\
\text { curriculum }\end{array}$} & 8 & 25 & 125 & 27 & 108 & 14 & 42 & 2 & 4 & 0 & 0 & 68 & 279 & 4.10 \\
\hline & 9 & 24 & 120 & 26 & 104 & 16 & 48 & 2 & 4 & 0 & 0 & 68 & 276 & 4.06 \\
\hline & 10 & 13 & 65 & 10 & 40 & 32 & 96 & 7 & 14 & 6 & 6 & 68 & 221 & 3.25 \\
\hline & 11 & 28 & 140 & 23 & 92 & 14 & 42 & 3 & 6 & 0 & 0 & 68 & 280 & 4.12 \\
\hline & 12 & 26 & 130 & 15 & 60 & 23 & 69 & 4 & 8 & 0 & 0 & 68 & 267 & 3.93 \\
\hline & 13 & 28 & 140 & 22 & 88 & 15 & 45 & 3 & 6 & 0 & 0 & 68 & 279 & 4.10 \\
\hline & 14 & 22 & 110 & 17 & 68 & 26 & 78 & 3 & 6 & 0 & 0 & 68 & 262 & 3.85 \\
\hline & 15 & 25 & 125 & 25 & 100 & 15 & 45 & 3 & 6 & 0 & 0 & 68 & 276 & 4.06 \\
\hline & \multicolumn{14}{|c|}{ Average Indicators $=31,47: 8=3,93$} \\
\hline \multirow{6}{*}{$\begin{array}{c}\text { c) Utilization of the } \\
\text { Internet as a means of learning } \\
\text { interaction with teachers }\end{array}$} & 16 & 15 & 75 & 5 & 20 & 37 & 111 & 7 & 14 & 4 & 4 & 68 & 224 & 3.29 \\
\hline & 17 & 10 & 50 & 6 & 24 & 36 & 108 & 14 & 28 & 2 & 2 & 68 & 212 & 3.12 \\
\hline & 18 & 9 & 45 & 8 & 32 & 41 & 123 & 10 & 20 & 0 & 0 & 68 & 220 & 3.24 \\
\hline & 19 & 6 & 30 & 21 & 84 & 30 & 90 & 10 & 20 & 1 & 1 & 68 & 225 & 3.31 \\
\hline & 20 & 3 & 15 & 7 & 28 & 33 & 99 & 25 & 50 & 0 & 0 & 68 & 192 & 2.82 \\
\hline & \multicolumn{14}{|c|}{ Average Indicators $=15,78: 5=3,16$} \\
\hline
\end{tabular}

The determination of the interpretation qualification and the value range of the consultation of the calculation result is based on the development of scale value determined by the researcher that is Liket scale. The result of the development is obtained the consultation table of the results of the calculation of the average trend as follows:

TABlE III. Consultation of Average Trend CAlCulation RESULTS

\begin{tabular}{|c|c|}
\hline VALUE RANGE & CRITERIA \\
\hline \hline $4,01-5,00$ & Very good \\
$3,01-4,00$ & Good \\
$2,01-3,00$ & Enough \\
$1,01-2,00$ & Low \\
$0,01-1,00$ & Very Low \\
\hline
\end{tabular}

In general, the average value of Internet Utility variable score of 3.58 means to indicate good qualification.
1. In general, the average value of Internet Utility variable score of 3.58 means to indicate good qualification. While the Internet as a medium of learning, the value of trends of 3.66 which means the meaning included in either category. These conditions indicate that students are considered well utilizing the Internet as a medium of learning. The use of the Internet as a learning resource / curriculum gained a 3.93 inclination value that implies a good category. These conditions indicate that students are well regarded utilizing the internet as a learning resource / curriculum. This is indicated by the statement of students who tend to declare always use the internet when looking for references related to internet material learning; Utilizing the Web when looking for references related to internet material learning; Utilizing online library sites when searching for references related to internet material learning; 
Using the internet while working on tasks related to internet material learning; Making the Internet as a complete source of learning related to internet material compared to other learning resources; Internet presents complete internet related material; The internet presents systematic internet-related material; And the Internet provides easily accessible internet-related material. The bill may be specially spelled out in the following indicators:

2. Utilization of the Internet as a means of learning interaction with teachers to obtain the value of the trend of 3.16, which means included in the category either. These conditions indicate that students are considered well utilizing the internet as a means of learning interaction with teachers. This is indicated by the statement of students who tend to declare teachers always deliver tasks via email; Presents material using the internet; Utilizing the internet when assigning group assignments; Utilizing the internet when assigning homework assignments; And utilizing the internet in providing evaluation questions.

\section{B. Variable Learning creativity (X2)}

Respondents in this study amounted to 68 students of SMK Negeri 2 Bandung. The results showed that the mean or average score of students' creativity is 83.94 with the standard deviation is 10.59. Range is a range between data minimun with maximun and known by 43. Minimun data of 64 with data Maximum 107. While the distribution of research data is presented in the table below.

TABLE IV. FREQUENCY DISTRIBUTION SCORE CREATIVITY LEARNING

\begin{tabular}{|c|c|c|c|c|c|}
\hline INTERVAL CLASS & $\mathbf{F}$ & $\mathbf{X}$ & $\mathbf{X}^{2}$ & FX & $\mathbf{F X}^{2}$ \\
\hline $107-102$ & 5 & 104.5 & 10920.25 & 522.5 & 54601.25 \\
\hline $101-96$ & 6 & 98.5 & 9702.25 & 591 & 58213.5 \\
\hline $95-90$ & 8 & 92.5 & 8556.25 & 740 & 68450 \\
\hline $83-78$ & 16 & 80.5 & 6480.25 & 1288 & 103684 \\
\hline $77-72$ & 10 & 74.5 & 5550.25 & 745 & 55502.5 \\
\hline $71-66$ & 8 & 68.5 & 4692.25 & 548 & 37538 \\
\hline $65-60$ & 1 & 62.5 & 3906.25 & 62.5 & 3906.25 \\
\hline & 68 & 668 & 57290 & 5708 & 486647 \\
\hline
\end{tabular}

The tendency to spread the distribution of learning creativity variable scores is presented as follows:

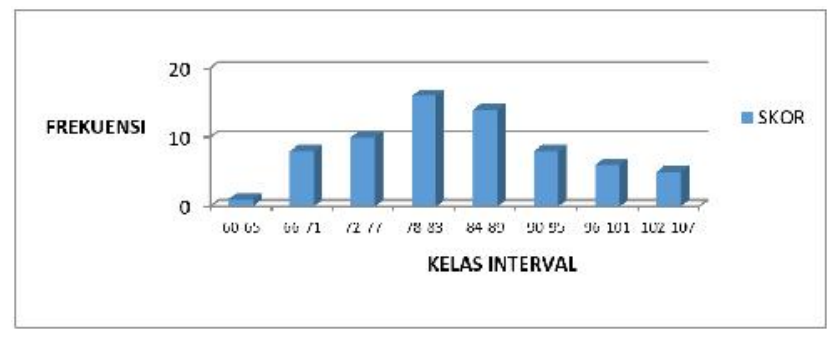

Fig. 3. Histogram Score Creativity learning

Further illustrations of learning creativity can be classified through the results table of the average tendency trends of respondents below (Table V).

In general, the average scores of learning creativity variable score of 3.54 means to indicate good qualification. While the picture can be specified in the following indicators:

1. Current in thinking obtains a tendency value of 3.43 which implies belonging to either category. The condition indicates that the student has been considered to ${ }^{1}$ have a smooth in thinking. This is indicated by the statement of students who tend to claim always dare to ask the teacher when having difficulty in understanding the material; Seeks to practice an understanding of the material presented by the teacher; Can overcome the difficulties in the lesson; Thinking excitedly so that the time of the lesson goes quickly.

2. Flexible thinking in the mind to get the value of the trend of 3.65 which means included in the good category. The condition indicates that the students have been considered to have flexibility in thinking well. Being able to elaborate gets a trend value of 3.62 which means included in either category. These conditions indicate that students are considered capable of elaborating. This is indicated by the statement of students who tend to declare always able to give opinions to others who disagree; Accustomed to doing the task in accordance with the provisions set by the teacher; Believes that you are able to complete the task as hard as any teacher does; Prefer to be rational in doing the task; Interested in KKPI subjects, both related to theory and practice; And feel happy when made as chairman in group learning activities. 
Able to spark a unique idea to get the value of a trend of 3.47 which means included in either category. The condition indicates that the students have been considered capable of sparking unique ideas well.

TABLE V. AVERAGE TREND OF LEARNING CREATIVITY SCORE AT SMK NEGERI 2 BANDUNG

\begin{tabular}{|c|c|c|c|c|c|c|c|c|c|c|c|c|c|c|c|}
\hline \multirow{3}{*}{ INDICATORS } & \multirow{3}{*}{ No. Item } & \multicolumn{11}{|c|}{ CATEGORY ANSWER } & \multirow{2}{*}{\multicolumn{2}{|c|}{ Score }} & \multirow{3}{*}{ Average } \\
\hline & & \multicolumn{3}{|c|}{5} & \multicolumn{2}{|c|}{4} & \multicolumn{2}{|c|}{3} & \multicolumn{2}{|c|}{2} & \multicolumn{2}{|c|}{1} & & & \\
\hline & & \multirow{2}{*}{\multicolumn{2}{|c|}{$\begin{array}{l}\mathbf{F} \\
8\end{array}$}} & $\mathbf{X}$ & $\mathbf{F}$ & $\mathbf{X}$ & $\mathbf{F}$ & $\mathbf{X}$ & $\mathbf{F}$ & $\mathbf{X}$ & $\mathbf{F}$ & $\mathbf{X}$ & $\mathbf{F}$ & $\mathbf{X}$ & \\
\hline \multirow{5}{*}{$\begin{array}{l}\text { Current in } \\
\text { thinking }\end{array}$} & $\overline{11}$ & & & 40 & 18 & 72 & 41 & 123 & $\overline{11}$ & 2 & 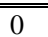 & 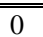 & 268 & 237 & 3.49 \\
\hline & 2 & \multicolumn{2}{|l|}{8} & 40 & 18 & 72 & 41 & 123 & 1 & 2 & 0 & 0 & 68 & 237 & 3.49 \\
\hline & 3 & \multicolumn{2}{|l|}{2} & 10 & 15 & 60 & 48 & 144 & 3 & 6 & 0 & 0 & 68 & 220 & 3.24 \\
\hline & 4 & \multicolumn{2}{|l|}{6} & 30 & 26 & 104 & 33 & 99 & 3 & 6 & 0 & 0 & 68 & 239 & 3.51 \\
\hline & \multicolumn{15}{|c|}{ Average Indicators $=13,72: 4=3,43$} \\
\hline \multirow{6}{*}{$\begin{array}{l}\text { Flexible in } \\
\text { thinking }\end{array}$} & 5 & \multicolumn{2}{|l|}{$\frac{13}{5}$} & 65 & 40 & 160 & 14 & 42 & 0 & 0 & 1 & 1 & 68 & 268 & 3.94 \\
\hline & 6 & 5 & & 25 & 33 & 132 & 28 & 84 & 2 & 4 & 0 & 0 & 68 & 245 & 3.60 \\
\hline & 7 & \multicolumn{2}{|l|}{5} & 25 & 33 & 132 & 28 & 84 & 2 & 4 & 0 & 0 & 68 & 245 & 3.60 \\
\hline & 8 & \multicolumn{2}{|l|}{7} & 35 & 30 & 120 & 29 & 87 & 2 & 4 & 0 & 0 & 68 & 246 & 3.62 \\
\hline & 9 & \multicolumn{2}{|l|}{6} & 30 & 27 & 108 & 30 & 90 & 5 & 10 & 0 & 0 & 68 & 238 & 3.50 \\
\hline & \multicolumn{15}{|c|}{ Average Indicators $=18,26: 5=3,65$} \\
\hline \multirow{7}{*}{$\begin{array}{l}\text { Be able to } \\
\text { elaborate }\end{array}$} & 10 & \multicolumn{2}{|l|}{8} & 40 & 31 & 124 & 27 & 81 & 2 & 4 & 0 & 0 & 68 & 249 & 3.66 \\
\hline & 11 & 12 & & 60 & 24 & 96 & 25 & 75 & 7 & 14 & 0 & 0 & 68 & 245 & 3.60 \\
\hline & 12 & 13 & & 65 & 12 & 48 & 35 & 105 & 8 & 16 & 0 & 0 & 68 & 234 & 3.44 \\
\hline & 13 & 15 & & 75 & 19 & 76 & 30 & 90 & 4 & 8 & 0 & 0 & 68 & 249 & 3.66 \\
\hline & 14 & 26 & & 130 & 28 & 112 & 10 & 30 & 4 & 8 & 0 & 0 & 68 & 280 & 4.12 \\
\hline & 15 & 13 & & 65 & 9 & 36 & 28 & 84 & 15 & 30 & 3 & 3 & 68 & 218 & 3.21 \\
\hline & & & & & & Avera & Indic & ors $=2$ & $69: 6$ & 3,62 & & & & & \\
\hline & & & & & & & EGOI & Y ANS & ER & & & & & & \\
\hline INDICA & ORS & No. Item & & 5 & & 4 & & & & & & & & & Average \\
\hline & & & $\mathbf{F}$ & $\mathbf{X}$ & $\mathbf{F}$ & $\mathbf{X}$ & $\mathbf{F}$ & $\mathbf{X}$ & $\mathbf{F}$ & $\mathbf{X}$ & $\mathbf{F}$ & $\mathbf{X}$ & $\mathbf{F}$ & $\mathbf{X}$ & \\
\hline & & 16 & 16 & 80 & 16 & 64 & 28 & 84 & 8 & 16 & 0 & 0 & 68 & 244 & 3.59 \\
\hline & & 17 & 11 & 55 & 20 & 80 & 31 & 93 & 5 & 10 & 1 & 1 & 68 & 239 & 3.51 \\
\hline & & 18 & 9 & 45 & 18 & 72 & 36 & 108 & 4 & 8 & 1 & 1 & 68 & 234 & 3.44 \\
\hline & & 19 & 14 & 70 & 18 & 72 & 31 & 93 & 5 & 10 & 0 & 0 & 68 & 245 & 3.60 \\
\hline a) $\mathbf{B e} \mathbf{a b}$ & to spark a & 20 & 12 & 60 & 13 & 52 & 36 & 108 & 6 & 12 & 1 & 1 & 68 & 233 & 3.43 \\
\hline unique & & 21 & 11 & 55 & 12 & 48 & 33 & 99 & 10 & 20 & 2 & 2 & 68 & 224 & 3.29 \\
\hline & & 22 & 6 & 30 & 16 & 64 & 38 & 114 & 8 & 16 & 0 & 0 & 68 & 224 & 3.29 \\
\hline & & 23 & 8 & 40 & 20 & 80 & 36 & 108 & 3 & 6 & 1 & 1 & 68 & 235 & 3.46 \\
\hline & & 24 & 12 & 60 & 21 & 84 & 32 & 96 & 3 & 6 & 0 & 0 & 68 & 246 & 3.62 \\
\hline & & & & & & & Averas & Indica & $\mathrm{rs}=3$ & $24: 9$ & 3,47 & & & & \\
\hline & & & & & & $\operatorname{tar}$ & $=14$ & $: 9=$ & & & & & & & \\
\hline
\end{tabular}

\section{Student Learning Outcomes Variable $(Y)$}

Respondents in this study amounted to 68 students of SMK Negeri 2 Bandung. The results showed that: Mean or average score of student learning outcomes is 7.46 with standard deviation is 0.58 . Range is a range between data minimun with maksimun and known at 2.71. Minimum data is 6,21 with Maximum data 8,62. While the distribution of research data is presented in the table below.

TABLE VI. FREQUENCY DISTRIBUTION OF STUDENT LEARNING RESULTS SCORE

\begin{tabular}{|c|c|c|c|c|c|}
\hline INTERVAL CLASS & $\mathbf{F}$ & $\mathbf{X}$ & $\mathbf{X}^{2}$ & FX & $\mathbf{F X}^{2}$ \\
\hline $8.62-8.29$ & 6 & 8.46 & 71.49 & 50.73 & 428.92 \\
\hline $8.28-7.95$ & 7 & 8.12 & 65.85 & 56.81 & 460.97 \\
\hline $7.94-7.61$ & 14 & 7.78 & 60.45 & 108.85 & 846.31 \\
\hline $7.60-7.27$ & 19 & 7.44 & 55.28 & 141.27 & 1050.31 \\
\hline $7.26-6.93$ & 10 & 7.10 & 50.34 & 70.95 & 503.39 \\
\hline $6.92-6.59$ & 6 & 6.76 & 45.63 & 40.53 & 273.78 \\
\hline $6.58-6.25$ & 4 & 6.42 & 41.15 & 25.66 & 164.61 \\
\hline \multirow[t]{2}{*}{$6.24-5.91$} & 2 & 6.08 & 36.91 & 12.15 & 73.81 \\
\hline & 68 & 58.12 & 427.09 & 506.94 & 3802.09 \\
\hline
\end{tabular}


The propensity to spread the distribution of learning creativity variable scores is presented in the figure below

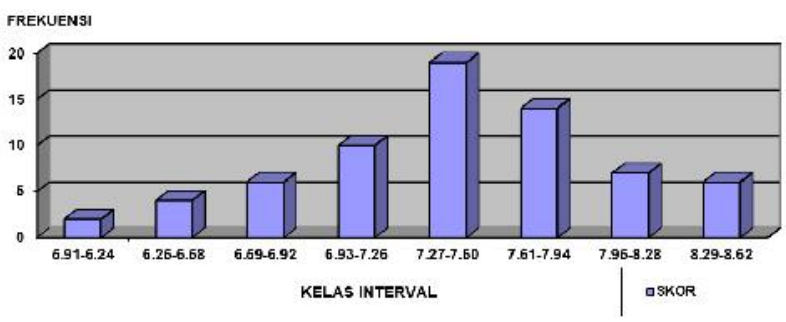

Fig. 4. Histogram Score Learning Outcomes

\section{CONCLUSION}

The results of research studies on the problem of "the contribution of Internet utilization and creativity of learning to student learning outcomes on subjects KKPI in SMK Negeri 2 Bandung" shows the following results:

1. The utilization rate of the internet in supporting the learning done by the students get the average value of the variable score of 3.58 shows good qualification.Tingkat kreativitas belajar siswa yang ditunjukkan dalam mengikuti mata pelajaran KKPI memperoleh nilai rata-rata skor variabel sebesar 3,54 menunjukan kualifikasi baik.

2. Students' learning outcomes in KKPI subjects obtained a grade point average of 7.61 indicates good qualification. The contribution of internet utilization of student learning outcomes on subjects KKPI in SMK Negeri 2 Bandung based on the calculation of coefficient of determination obtained $27.04 \%$. This means that the use of the Internet contributes $27.04 \%$ of student learning outcomes on subjects KKPI.

3. The large contribution of learning creativity to student learning outcomes on subjects KKPI in SMK Negeri 2 Bandung based on the calculation of coefficient of determination obtained $42.25 \%$. This means that students' creativity contributes $42.25 \%$ of student learning outcomes on KKPI subjects.
4. The contribution of internet utilization and creativity of learning to student learning outcomes on subjects KKPI in SMK Negeri 2 Bandung based on the calculation of coefficient of determination obtained by $21.16 \%$. This means that between the use of the internet and students 'learning creativity together contributes $21.16 \%$ to the students' learning outcomes on KKPI subjects.

\section{REFERENCES}

[1] Ali, M. (1985). Penelitian Pendidikan : Prosedur dan Strategi. Bandung:Angkasa.

[2] Arikunto, S (1986) Prosedur Penelitian Suatu Pendekatan Praktis. Jakarta : Bumi Aksara..

[3] Munandar, S.C.U (1992). Mengembangkan Bakat dan Kreativitas Anak Sekolah: Petunjuk Bagi Guru dan Orang Tua. Jakarta: Gramedia Widiasarana Indonesia.

[4] Munandar, Utami (2004). Cetakan Kedua. Pengembangan Kreativitas Anak Berbakat. Jakarta: PT Rineka Cipta.

[5] Oetomo, Budi. S. D. 2002. E-Education-Konsep, Teknologi dan Aplikasi Internet Pendidikan. Yogyakarta: Andi

[6] Ramdhan, Arief (2005), "Internet dan Aplikasinya", Jakarta, PT. Elex Media Komputindo.

[7] Supriadi, D (2002). Kreativitas, Kebudayaan, dan Perkembangan Iptek. Bandung: Alfabeta.

[8] Surakhmad. W. (1985). Dasar dan Teknik Research.Bandung : Tarsito.

[9] Sutisna, O. (1985). Administrasi Pendidikan, Dasar Teoritis Untuk Praktek Profesional, Bandung : Angkasa.

[10] Hakim, Thursan (2005), Belajar Secara Efektif, Jakarta: Puspa Swara.

[11] Slameto, (2003), Belajar dan Faktor-faktor Yang Mempengaruhinya. Jakarta: Rineka Cipta.

\section{Internet Sources:}

[12] Depdiknas (2003).Undang-Undang Republik Indonesia No. 20 Tahun 2003 Tentang Sistem Pendidikan Nasional. Tersedia: http://depdiknas.go.id [12 Februari 2009].___, (2006). Rencana Strategis Departemen Pendidikan Nasional Tahun 2005-2009, Tersedia: http://depdiknas.go.id [12 Februari 2009]

[13] Hardjito, Internet untuk Pembelajaran; [online] Tersedia:http://nayel.multiply.com/journal/item/11 [4 Februari 2009] 